\title{
Right To Education And Teacher Gap In Nigeria: Estimating The Problem And Lessons From International Best Practices
}

\author{
Steve Nwokeocha \\ Professor \& Executive Director \\ Africa Federation of Teaching Regulatory Authorities \\ Abuja, Nigeria \& Centurion, South Africa
}

\begin{abstract}
This paper was first presented as the 2018 Distinguished Guest Paper at Nigeria's Annual World Teachers' Day Symposium. The theme of the 2018 World Teachers' Day, which is "Right to education means the right to a qualified teacher" therefore, provides the context. The paper examines the main thrusts of the 1966 International Labour Organisation (ILO)/United Nations Educational, Scientific and Cultural Organisation (UNESCO) Recommendation concerning the Status of Teachers and 1997 UNESCO recommendation concerning the status of higher education teaching personnel which laid a strong foundation for the professionalization of teaching and gave birth to the World Teachers' Day. It argues that the theme of the World Teachers' Day calls for a balance between the promises of the right to education and implementation of the 1996 ILO/UNESCO and 1997 UNESCO Recommendations. Against this background, the paper $x$-rays the concept and dimensions of the right to education as intended by the international conventions and international education goals. It also discusses the approaches to determining out-of-school children and interrogates the figures of outof-school children and the teacher gap in Nigeria. It finally discusses some international best practices regarding the right to education and the strategies of the African authorities to tackle the teacher gap in the continent and provides some recommendations for Nigeria.
\end{abstract}

Keywords: education, right, teacher, quality.

\section{INTRODUCTION}

This paper is a contribution to the debate around the theme of the 2018 World Teachers' Day (WTD). The theme is, "Right to education means the right to a qualified teacher" [1]. October 5 every year is celebrated globally as the World Teachers Day (WTD). The 2018 WTD was the $52^{\text {nd }}$ Anniversary of the adoption of the 1966 ILO/UNESCO Recommendation concerning the Status of Teachers and its corollary, the 1997 UNESCO recommendation concerning the status of higher education teaching personnel [2,3]. The 1966 ILO/UNESCO Recommendation ingrained teaching as a profession and covered the following specific issues among others: teachers' initial and on-going professional education, recruitment and career progression, job security and disciplinary processes. Others are professional autonomy, performance evaluation, rights and obligation, participatory management and general conditions to boost teaching and learning [2]. It emphasized that teaching is a profession that requires professional knowledge, skills, continuing education, and sense of responsibility to discharge the onerous task of facilitating learning. Similarly, the 1977 UNESCO Recommendation established the rights and obligations of teachers in higher institutions of learning. The basic fact emanating from the Recommendation is that teachers in the higher institutions are equally professionals in their own rights and require expertise, competences and enabling conditions of work that can truly make the institutions the base of research, innovation and development [3]. 
The theme of the 2018 WTD celebration once again brought to the fore the concern for the right to education and how this depends on the availability of qualified teachers. The fact that the 2018 WTD equated the right to education with the right to a qualified teacher implied that there should be a balance between the promises of the right to education and the level of implementation of the UNESCO and ILO Recommendations. Put differently, unless the Recommendations are matched with action, the right to education will be impaired or denied. The 2018 WTD therefore provides the context for this paper which critically examines the right to education in Nigeria, paying special attention to the two sides of the issue - the right to education and availability of the right quantity and quality of teachers. Accordingly, the paper deals with the following matters: (a) Concept and dimensions of the right to education as contained in the international conventions and international education goals; (b) Approaches to determining out-of-school children; (c) Estimating the out-of-school children in Nigeria; (d) Estimating the teacher gap in Nigeria, that is the dearth of quantity and quality of teachers in Nigeria; (e) Some international best practices regarding the right to education; (f) A model that illustrates what the education authorities in Africa are doing to address the teacher gap; and finally (g) recommendations for Nigeria.

\section{METHDOLOGY}

This was the 2018 Distinguished Guest Paper presented at the Nigeria Annual Symposium to mark the WTD organised by Nigeria's Federal Ministry of Education and a coalition of national and international stakeholders including the Nigeria Union of Teachers. The paper was based on three key sources of information: desk review of literature, practical experiences of the author and views of a panel of discussants which deliberated on the paper after its presentation at the Symposium. The Nigeria's Minister of Education invited the author to discuss his experiences as Director previously responsible for the regulation of teaching in Nigeria and currently the Executive Director of the Africa Federation for the Regulation of Teaching (AFTRA). AFTRA is an intergovernmental organisation working with the African Union, UNESCO-IICBA, Education International Africa Region and other critical stakeholders to regulate teaching at the continental level. The author is also member of global organisations such as the International Task Force on Teachers for Education 2030 and World Forum of Teaching Regulatory Authorities. The experiences of the author in these capacities therefore were important sources of the information in this paper. The high-level panel of discussants at the Symposium that analysed the issues raised in the presentation comprised the chief executive officers of the relevant national agencies (Teachers Registration Council of Nigeria, National Teachers Institute, Universal Basic Education Commission, National Commission for Colleges of Education, National Universities Commission and others) and the Nigerian Union of Teachers. The views and consensus of the panel were noted by the author and reflected in this final (though abridged) paper. Therefore the information and data in this paper could be relied upon as the very latest trending in Nigeria and the author further ensured that the statistics used were the most recent from UNESCO and other relevant international authorities.

\section{CONCEPT AND DIMENSIONS OF THE RIGHT TO EDUCATION}

This section articulates the concept and dimensions of the right to education as contained in the international conventions and international education goals. A human right is a natural endowment universally considered inalienable. When the thirteen States of America declared independence from Britain on July 4, 1776 they stated that it was based on truths that are selfevident and natural. This was a reference to human right. They asserted that human beings are created equal and the creator has given everyone right to life, liberty and happiness [4]. Human rights are therefore issues that the human society believes to be innate and undeniable and to which every human being is equally entitled. Among these are right to life, education, peaceful assembly, religious belief, family, and freedom of expression. Patel [5] described the right to 
education as an integral part of the freedom of thought and the dignity of human person and [6] affirmed that human rights are undeniable.

The first attempt to comprehensively articulate and establish human rights at the global level came with the Universal Declaration of Human Rights [7]. Article 1 of the Declaration reechoed the truth that human beings are "born free and equal in dignity and rights." The rights listed in the Declaration included life, liberty, security, equality before the law, privacy and family. Others are movement, residence, nationality, property, opinion, association, work, leisure, health, education, culture and so forth. However, Article $\mathbf{2 6}$ of the Declaration gave more detail of what constitutes the right to education. It stated that right to education shall entail free basic education and accessible technical, professional and higher education with merit as the guiding principle. It further declared that education shall be used for full development of the human potential and to promote inter-cultural and global brotherhood, and parents shall have freedom to choose the sort of education good for their children (see Box 1).

\section{Box 1: Article 26 of the Universal Declaration of Human Rights, 1948 [7]}

1. Everyone has the right to education. Education shall be free, at least in the elementary and fundamental stages. Elementary education shall be compulsory. Technical and professional education shall be made generally available and higher education shall be equally accessible to all on the basis of merit.

2. Education shall be directed to the full development of the human personality and to the strengthening of respect for human rights and fundamental freedoms. It shall promote understanding, tolerance and friendship among all nations, racial or religious groups, and shall further the activities of the United Nations for the maintenance of peace.

3. Parents have a prior right to choose the kind of education that shall be given to their children.

Since the Declaration, multiples of conventions and charters have emerged to elaborate, capture more dimensions and engrave not just the right to education but all other rights. Some of these conventions were under the auspices of the United Nations, UNESCO, International Labour Organisation and continental organisations like the African Union. There are also humanitarian laws represented by the various Geneva Conventions on the treatment of prisoners of war, protections of civilians in time of war, protection of victims of international conflict, and others. These instruments together have complex implications for the right to education. Box 2 provides outlines of some of the international instruments. 


\section{Box 2: Selected international instruments on right to education}

\section{United Nations [8]}

- Universal Declaration of Human Rights, 1948 - Article 26

- International Covenant on Economic, Social and Cultural Rights, 1966 Article 13 and 14

- Convention on the Rights of the Child, 1989 - Article 28 and 29

- Convention on the Elimination of All Forms of Discrimination against Women, 1979 - Article 10

- Convention on the Rights of Persons with Disabilities, 2006 - Article 24

- Declaration on Human Rights Education and Training, 2011

\section{UNESCO}

- UNESCO Convention against Discrimination in Education, 1960

- UNESCO Convention on Technical and Vocational Education, 1989

\section{International Labour Organisation}

- ILO Convention No. 138 on the minimum age for employment, 1973

- ILO Convention No. 182 on Worst Forms of Child Labour, 1999

- ILO Convention No. 169 concerning Indigenous and Tribal Peoples in Independent Countries, 1989

\section{African Union:}

- African Charter on Human and People's Rights, 1981 - Article 17 and 25

- African Charter on the Rights and Welfare of the Child, 1990 - Article 11

- African Youth Charter, 2006 - Article 13

Over the years, especially from the 2000s, the right to education has been expatiated by the international education goals, targets and strategies such as Education For All (EFA) [9,10]; Millennium Development Goals (MDG) [11]; and the Sustainable Development Goals (SDG) [12]. At the Africa level, there are also Agenda 2063: The Africa We Want [13] and Continental Education Strategy for Africa (CESA 2016-2025) [14] which serve as the domestication of the international education goals for implementation at the continental level. The EFA goals advocated the expansion of access to early childhood care and education; free, compulsory and universal primary education; increase in adult literacy by 50 per cent; actualisation of gender parity and equality; and improved quality of education [9]. Both the MDG2 and SDG4Education expanded and envisioned a more vigorous pursuit of the EFA goals. Table 1 presents the comparison of the key features of the education goals set over the years for the right to education. UNICEF and UNESCO [15] emphasized that to achieve the right to education, access to education, quality of education and respect to the rights of the child in the education system are key. 
Table 1: Global education goals compared [16]

\begin{tabular}{|l|l|l|l|}
\hline Scope & \multicolumn{1}{|c|}{ MDG2 } & \multicolumn{1}{c|}{ EFA } & \multicolumn{1}{c|}{ SDG4 } \\
\hline $\begin{array}{l}\text { Education } \\
\text { (children) }\end{array}$ & $\begin{array}{l}\text { Basic Education } \\
\text { (children, youth \& adults) }\end{array}$ & $\begin{array}{l}\text { Basic Education; } \\
\text { Post Basic Education and } \\
\text { Training; } \\
\text { Lifelong perspective }\end{array}$ \\
\hline $\begin{array}{l}\text { Geo- } \\
\text { graphical } \\
\text { coverage }\end{array}$ & $\begin{array}{l}\text { Low-income } \\
\text { countries, } \\
\text { Conflict-affected }\end{array}$ & $\begin{array}{l}\text { While universal in intention, } \\
\text { in practice it focused on } \\
\text { lower-income countries }\end{array}$ & $\begin{array}{l}\text { Universal agenda for all } \\
\text { countries regardless of } \\
\text { income level and/ or } \\
\text { development status }\end{array}$ \\
\hline $\begin{array}{l}\text { Policy } \\
\text { focus }\end{array}$ & $\begin{array}{l}\text { Access to and } \\
\text { completion of } \\
\text { primary education } \\
\text { for all }\end{array}$ & $\begin{array}{l}\text { Access to quality basic } \\
\text { education for all }\end{array}$ & $\begin{array}{l}\text { Access to quality basic } \\
\text { education for all; } \\
\text { Equitable access to post- } \\
\text { basic } \\
\text { education \& training; } \\
\text { Relevance of learning } \\
\text { for both work and 'global } \\
\text { citizenship' }\end{array}$ \\
\hline
\end{tabular}

The SDG4-Education 2030, which is now the overarching education goal states as follows:

\section{"Ensure inclusive and equitable quality education and promote lifelong learning opportunities for all." [12]}

UNESCO [17] provided the SDG4 strategic approaches, targets, indicators and means of implementation. The documents highlighted the keywords of SDG4 as access to education, equity and inclusion, gender equality, education quality, and lifelong learning. It then outlined the strategic approaches as follows:

i. $\quad$ Strengthening policies, plans, legislation and systems.

ii. Emphasizing equity, inclusion and gender equality.

iii. Focusing on quality and learning.

iv. Promoting lifelong learning.

v. Addressing education in emergency situations.

UNESCO [17] further created seven targets (4.1 to 4.7) and another three targets (4.a to 4.c). For instance, target 4.1 states that: "By 2030, ensure that all girls and boys complete free, equitable and quality primary and secondary education leading to relevant and effective learning outcomes". Overall, SDG4 targets 4.1 to 4.7 cover early childhood development, care and preprimary education; primary and secondary education; technical, vocational and tertiary education, including university; entrepreneurship; education for the vulnerable, persons with disabilities, indigenous peoples and children in vulnerable situations; literacy and numeracy; and promotion of a culture of peace and non-violence [17]. However, target 4.c focuses specifically on the teachers and states that: "By 2030, substantially increase the supply of qualified teachers, including through international cooperation for teacher training in developing countries, especially least developed countries and small island developing States." Target 4.c therefore directly links the right to education to the right to a qualified teacher - the theme of the WTD.

In an excellent publication captioned "Rethinking education towards a global common good?" written in support of the SDG4-Education, UNESCO [18] advocated a new approach to education to build a common humanity. It suggested that individuals should see themselves as the leaves of a tree and the tree is all of humanity. No one can live without the other. Also, 
quoting Desmond Tutu of South Africa, UNESCO (2015b) states, "My humanity is bound up in yours, for we can only be human together" (p.36). This philosophy is indeed common in the cultures of the peoples of Southern Africa and they call it Ubuntu - I am because you are! UNESCO [18] therefore urged that "we must recognise the diversity of lived realities while reaffirming a common core of universal values" (p. 29). At the centre of these assertions is the right to education as a core universal value. Humanity can be humane, inclusive, blossoming and attaining the greatest height possible only if the right to education is fully and absolutely realised.

\section{APPROACHES TO DETERMINING OUT-OF-SCHOOL CHILDREN}

All over the world, the effort to implement the right to education has warranted a focus on the number of children that are out-of-school. To do this satisfactorily, it is important to understand the approaches to and aspects of out-of-school children enunciated by UNICEF and UNESCO Institute for Statistics (UIS). This is important because education data and education management information system of any country must be in line with the parameters set by these international organs so that such data can be internationalised and integrated into the global education management information system. Therefore, three of such approaches are discussed in this section: (i) exposure to education; (ii) five dimensions of exclusion; and (iii) three groups of visibility [19]. UNICEF \& UIS believed that these approaches can help to view, capture and analyse the data on out-of-school children.

\section{i. Exposure to education}

According to this approach, there are two groups of out-of-school children; they are those who had entered but dropped out and those who have not entered. Among the later are those who will enter late and those who will never enter. This is illustrated by figure 1.

Figure 1: Classification of the out-of-school population, by school exposure [19]

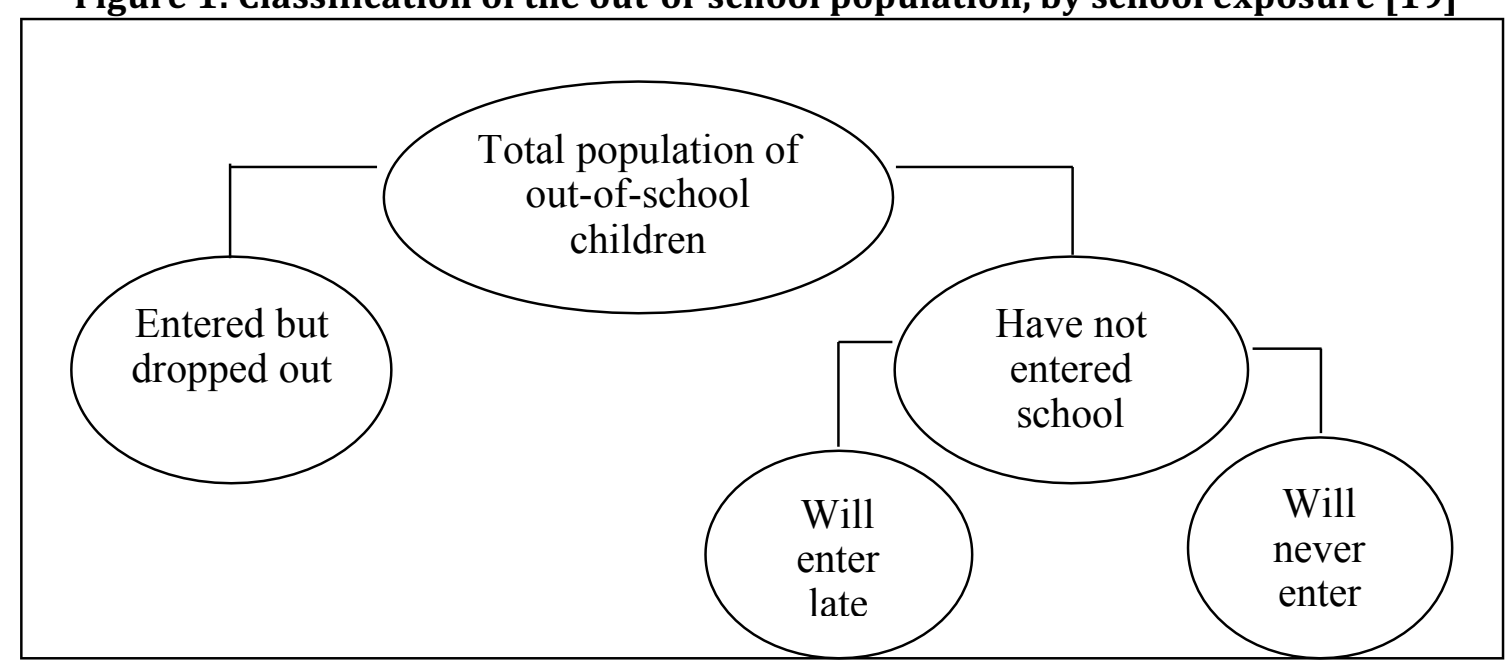

\section{ii. Five dimensions of exclusion}

This approach presents five categories of out-of-school children. The first three categories are children who ought to be in the pre-primary, primary, and lower secondary schools but are not there. The last two categories are children who are in the primary and lower secondary schools but run the risk of dropping out.

Table 2 illustrates a combination of the first two approaches (exposure to education and five dimensions of exclusion) to the study of out-of-school children 
Table 2: The five dimensions of exclusion [19]

\begin{tabular}{|c|c|c|c|c|c|c|c|}
\hline Dimension 1 & \multicolumn{3}{|c|}{ Dimension 2} & \multicolumn{3}{|c|}{ Dimension 3} & \multirow{3}{*}{$\begin{array}{l}\text { OUT OF } \\
\text { SCHOOL }\end{array}$} \\
\hline $\begin{array}{l}\text { Not in pre- } \\
\text { primary or } \\
\text { primary school }\end{array}$ & $\begin{array}{l}\text { Attended } \\
\text { but } \\
\text { dropped out }\end{array}$ & $\begin{array}{l}\text { Will } \\
\text { enter } \\
\text { later }\end{array}$ & $\begin{array}{l}\text { Will } \\
\text { never } \\
\text { enter }\end{array}$ & $\begin{array}{l}\text { Attended } \\
\text { but } \\
\text { dropped out }\end{array}$ & $\begin{array}{l}\text { Will } \\
\text { enter } \\
\text { later }\end{array}$ & $\begin{array}{l}\text { Will } \\
\text { never } \\
\text { enter }\end{array}$ & \\
\hline $\begin{array}{l}\text { Pre-primary } \\
\text { age children }\end{array}$ & \multicolumn{3}{|c|}{ Primary age children } & \multicolumn{3}{|c|}{$\begin{array}{l}\text { Lower secondary age } \\
\text { children }\end{array}$} & \\
\hline
\end{tabular}

\begin{tabular}{|c|c|c|}
\hline Dimension 4 & Dimension 5 & \multirow{3}{*}{ IN SCHOOL } \\
\hline $\begin{array}{l}\text { At risk of dropping } \\
\text { out of } \\
\text { primary school }\end{array}$ & $\begin{array}{l}\text { At risk of dropping out } \\
\text { of } \\
\text { lower secondary school }\end{array}$ & \\
\hline $\begin{array}{l}\text { Primary school } \\
\text { students }\end{array}$ & $\begin{array}{l}\text { Lower secondary } \\
\text { students }\end{array}$ & \\
\hline
\end{tabular}

Source: UNICEF \& UNESCO Institute for Statistics (2015:11)

\section{iii. Three groups of visibility}

This approach highlights the fact that not all out-of-school children are visible; that those captured in the records of the ministries of education, schools and other official organs are not all the out-of-school children in a country. It therefore delineated out-of-school children into three such as the visible being those found in official records; semi-invisible being unrecorded drop-outs and those not enrolled in school; and invisible being those not captured by the records of any school or government.

The three approaches analysed above are critical for a comprehensive mapping and profiling of the out-of-school children in any country and Nigeria should take good note of these in its effort to implement the right to education.

\section{ESTIMATING THE OUT-OF-SCHOOL CHILDREN IN NIGERIA}

One of the most important steps towards implementing the right to education is to have an accurate enumeration of the out-of-school children. At the global level, the UIS has a good account of the out-of-school children but the figure for Nigeria is highly debatable. This section therefore reviews the figures trending at the global level as well as the figure assigned to Nigeria. The case of the out-of-school children in Nigeria has become an issue not only of national but also global concern with Nigeria now declared as the country with the highest number of out-of-school children in the world. This reality is a serious challenge to the country and the global community. It equally means that accurate figure needs to be established and something drastic in terms of policy backed with action must take place if Nigeria must be part of the success stories of the SDGs by the year 2030. Resolving the out-of-school challenge is important because the other sixteen goals of the SDGs are said to depend directly and indirectly on the accomplishment of the SDG4-Education.

At this juncture, the paper takes a cursory look at the international figures and reports and then narrows down to the situation in Nigeria. The UIS [20] indicates that "One in five children, adolescents and youth is out of school" and asserts that there is "no progress in reducing the out-of-school numbers." It made this assertion of lack of progress based on its report that early in the 2000s, the number of out-of-school children declined rapidly by millions every whereas since 2012 the decline is just about a million globally per year. Therefore, the UIS sees this as lack of significant improvement in the situation. Overall, it put the global out-of-school figure at 263 million as captured in the table 3. 
Table 3: Global out-of-school children, adolescents and youth in millions, 2000 and 2016 [20]

\begin{tabular}{|l|l|c|c|}
\hline Level & & $\mathbf{2 0 0 0}$ & $\mathbf{2 0 1 6}$ \\
\hline \multirow{2}{*}{ Lpper secondary } & Female & 92.7 & 67.4 \\
\cline { 2 - 4 } & Male & 84.4 & 71.1 \\
\hline \multirow{2}{*}{ Primary } & Female & 54.0 & 30.0 \\
\cline { 2 - 4 } & Male & 45.7 & 31.1 \\
\hline Total & Female & 58.3 & 34.3 \\
\cline { 2 - 4 } & Male & 42.5 & 29.1 \\
\hline \multicolumn{2}{|l}{} & $\mathbf{3 7 7 . 5}$ & $\mathbf{2 6 3 . 0}$ \\
\hline
\end{tabular}

At the African level, sub-Saharan Africa is said to have the biggest share of the out-of-school children, having 96.9 million (36.8\%) of the global 263 million; it has the highest out-of-school rate of 32.3\%; and again, more sub-Saharan girls are out of school than boys, with out-ofschool rates of $35.1 \%$ and $29.6 \%$ for girls and boys, respectively [20]. Table 4 shows the relative position of sub-Saharan Africa to the rest of the world in terms of the out-of-school children.

Table 4: Out of school children by regions of the world, 2018 [20]

\begin{tabular}{|l|c|c|c|c|c|c|c|}
\hline $\begin{array}{l}\text { Out-of-school children, adolescents and youth of primary, lower secondary and upper } \\
\text { secondary age }\end{array}$ & \multicolumn{3}{|c|}{ Out-of-school rate (\%) } & \multicolumn{1}{l|}{ Out-of-school number (millions) } \\
\cline { 2 - 9 } & $\begin{array}{c}\text { Both } \\
\text { sexes }\end{array}$ & Male & Female & GPIA & $\begin{array}{c}\text { Both } \\
\text { sexes }\end{array}$ & Male & Female \\
\hline Region & 4.3 & 4.6 & 3.9 & 0.85 & 6.2 & 3.4 & 2.8 \\
\hline $\begin{array}{l}\text { Europe and Northern } \\
\text { America }\end{array}$ & 9.9 & 10.4 & 9.4 & 0.90 & 12.7 & 6.8 & 5.9 \\
\hline $\begin{array}{l}\text { Latin America and the } \\
\text { Caribbean }\end{array}$ & 7.6 & 6.8 & 8.4 & 1.20 & 1.0 & 0.5 & 0.6 \\
\hline Central Asia & 22.4 & 21.9 & 22.8 & 1.04 & 95.8 & 49.2 & 46.5 \\
\hline Southern Asia & 9.0 & 9.7 & 8.2 & 0.84 & 31.0 & 17.6 & 13.4 \\
\hline $\begin{array}{l}\text { Eastern and South-Eastern } \\
\text { Asia }\end{array}$ & 17.1 & 15.4 & 18.8 & 1.18 & 18.5 & 8.6 & 10.0 \\
\hline $\begin{array}{l}\text { Northern Africa and Western } \\
\text { Asia }\end{array}$ & $\mathbf{3 2 . 3}$ & $\mathbf{2 9 . 6}$ & $\mathbf{3 5 . 1}$ & $\mathbf{1 . 1 6}$ & $\mathbf{9 6 . 9}$ & $\mathbf{4 4 . 7}$ & $\mathbf{5 2 . 2}$ \\
\hline sub-Saharan Africa & 11.5 & 12.1 & 10.8 & 0.90 & 0.9 & 0.5 & 0.4 \\
\hline Oceania & 17.8 & 17.2 & 18.5 & 1.07 & 263.0 & 131.3 & 131.7 \\
\hline World
\end{tabular}

Notes:

GPIA = adjusted gender parity index (female/male out-of-school rate).

Besides the issue of out-of-school, the UIS [20] also announced that even the children in school fail to meet the expected proficiency at the completion of their primary education. The figure is as high as 617 million globally, which the UIS estimated to be about $60 \%$ (six out of ten) of the global number of children in school. Of the 617 figure, 387 million are in the primary school while 230 million are in the lower secondary school. Again, sub-Saharan Africa has the highest proportion of the children in school who do not meet the required proficiency level - the figure for Africa is 202 million children. "Across the region, nearly nine out of ten kids between the ages of about 6 and 14 are not gaining minimum proficiency levels in reading and mathematics" [20]. The UIS opined that the very high figure of children who are unable to meet the expected proficiency level signals "a learning crisis" which is a threat to the actualisation of the SDG4-Education.

Now to the Nigerian scenario, the dearth of data poses a challenge but the UIS [21] and UNICEF [22] have some figures for the country. The table 5 indicates that there are 8.7 million Nigerian 
children of primary school age that are out-of-school (the data for secondary education level was not supplied).

Table 5: Nigeria's out-of-school children compared with selected countries (millions) [21]

\begin{tabular}{|l|c|c|c|}
\hline \multicolumn{1}{|c|}{ Country } & Primary age & Lower secondary age & Upper secondary age \\
\hline India & 2.9 & 11.1 & 46.8 \\
\hline Pakistan & 5.6 & 5.4 & 9.8 \\
\hline Nigeria & 8.7 & Not supplied & Not supplied \\
\hline Ethiopia & 2.2 & 4.6 & 3.3 \\
\hline Niger & 1.2 & 1.2 & 1.0 \\
\hline Mali & 1.2 & 0.6 & 0.8 \\
\hline Sudan & 2.7 & 0.7 & Not supplied \\
\hline Mexico & 0.3 & 1.0 & 3.0 \\
\hline Nrazil & 0.8 & 0.7 & 1.7 \\
\hline
\end{tabular}

According to UNICEF [22], Nigeria has 10.5 million out-of-school children, which it described as the highest for any country in the world. It further stated that $60 \%$ of the figure is in the northern part of the country. However, there are indications that the 10.5 million is extremely conservative and the following are the reasons:

i. If Nigeria has 10.5 million children out of school, and 8.7 million of these are at the primary according to the UIS (table 5), it means that only 1.8 million children are out-ofschool at the lower secondary. This is untrue. For instance, countries on the table with lesser out-of-school children at the primary than Nigeria have more than 1.8 million out-of-school children at the lower secondary. That is, the out-of-school for lower secondary in India is 11.1 million, Pakistan 5.4 million, and Ethiopia 4.6 million. It is therefore unlikely that Nigeria has a figure less than 4.6 million (Ethiopia's figure) at the lower secondary.

ii. Some sources $[23,24,25]$ have asserted that the almajiris (the itinerant pupils of the basic Qur'anic schools) who are of primary and lower secondary school age but not enrolled in the formal education system are over 9 million. However, the almajiris come exclusively from the Muslim families mostly in the Northern part of Nigeria; then what about the children of other non-.Muslim families in the rest of the country who are not in school? Certainly, the out-of-school children who are not almajiris can be well over 4.5 million.

iii. In the last ten years, the out-of-school for primary and lower secondary for Nigeria has remained largely unchanged as 10 million on the average. The figure at the primary school level alone remained consistent at about 8 million (e.g. 8,455,579 for 2008; $8,462,200$ for $2009 ; 8,735,046$ for 2010 ; and 8.7 million for 2016) [26, 21]. A figure that is expected to be dynamic but which has proven to be static over a long period of time raises some doubt.

iv. Nigeria's population has increased from about 123 million in 2000 to an estimated 200 million (61.5\% increase) in 2018 and currently has a median age of 17.9 years [27]. These dynamics ought to reflect in the out-of-school figures.

From the foregoing, it is compelling to suggest that Nigeria needs to re-authenticate its out-ofschool figure. But at the meantime, it can be safely stated that Nigeria may have no less than 15 million out-of-school children at the primary and lower secondary school levels.

Again, there are also the children in school in Nigeria but who are not really learning much. Some sources reported a low level of proficiency in reading, mathematics and other subjects 
for the children in the school $[28,29]$. This corroborates the report by the UIS [20] that the children do not meet the required level of proficiency.

However, at the inception of the Millennium Development Goals, Nigeria joined the rest of the world to take drastic measures to improve access to and quality of basic education. At that time, it enacted laws for the universal, free and compulsory education, mass literacy, and nomadic education and set up national commissions such as the Universal Basic Education Commission; National Commission for Nomadic Education; and National Commission for Mass Literacy, Adult and Non-Formal Education [30, 31, 32]. In addition, the Constitution of the Federal Republic of Nigeria, 1999 [33] has strong provisions for the right to education. But, despite these efforts, the country has been unable to exit the unenviable position of the country with the highest out-of-school children in the world. The reasons are many but among them is the very high population growth rate $(2.6 \%)$ which outstrips the rate of economic growth and ability of the government to provide basic educational infrastructure and facilities as well as the persistent poverty level. In fact, the country went into recession with a Gross Domestic Product (GDP) growth rate of $-2.34 \%$ in 2016 and -0.91 in 2017 and just emerging from that recession with a rate of $1.95 \%$ in 2018 [34]. Also, $67 \%$ of Nigerians are said to live below the poverty line according to Maryam Uwais, Special Advisor to the President on Social Protection [35]. Uwais listed high rates of poverty, unemployment and illiteracy; rising insecurity; and gender inequality as leading factors that are weighing down efforts of the government to transform the country. Furthermore, the latest World Bank ranking of countries based the human development index gave Nigeria a position of 152 out of 157 countries [36].

There is also a World Bank study [37]) which documented Nigeria's position relative to peers with regards to tackling access to basic education. With focus on the gross enrolment ratio (GER), retention rate and out-of-school children statistics the study grouped the countries' basic education systems into four, namely: established, emerged, emerging and delayed. The study further considered the extent of challenges faced by each country in the 1990s. Seven of such challenges were huge total population, explosion in school enrolment, low or stagnant rate of growth of the Gross Domestic Product (GDP) per capita, high level of poverty, high income inequality, diversity of languages and recurring conflict. Based on these issues the countries were also grouped and Nigeria belongs to the group with many challenges and whose access to basic education is still 'emerging' as depicted on the table 6. 
Table 6: Progress in primary education relative to baseline challenges, sub-Saharan African countries, by group, 1990-2015 [37]

\begin{tabular}{|c|c|c|c|c|}
\hline $\begin{array}{l}\text { Extent of } \\
\text { challenges in } \\
\text { the } 1990 \mathrm{~s}\end{array}$ & $\begin{array}{c}\text { Group 1: } \\
\text { Established }\end{array}$ & $\begin{array}{l}\text { Group 2: } \\
\text { Emerged }\end{array}$ & $\begin{array}{l}\text { Group 3: } \\
\text { Emerging }\end{array}$ & $\begin{array}{l}\text { Group 4: } \\
\text { Delayed }\end{array}$ \\
\hline Few & $\begin{array}{l}\text { Bostwana, Cabo } \\
\text { Verde, Ghana, } \\
\text { Lesotho, } \\
\text { Mauritius, Sao } \\
\text { Tome and } \\
\text { Principe, } \\
\text { Swaziland }\end{array}$ & Comoros & $\begin{array}{l}\text { Benin, } \\
\text { Mauritania }\end{array}$ & \\
\hline Some & $\begin{array}{l}\text { Congo Republic, } \\
\text { Gabon, Namibia }\end{array}$ & $\begin{array}{l}\text { Cameroon, } \\
\text { Malawi, } \\
\text { Tanzania, } \\
\text { Togo }\end{array}$ & $\begin{array}{l}\text { Cote d'Ivoire, } \\
\text { The Gambia, } \\
\text { Guinea Bissau, } \\
\text { Madagascar, } \\
\text { Sierra Leone, } \\
\text { Zambia }\end{array}$ & $\begin{array}{l}\text { Burkina Faso, } \\
\text { Guinea, Mali, } \\
\text { Senegal }\end{array}$ \\
\hline Many & $\begin{array}{l}\text { Kenya, South } \\
\text { Africa, } \\
\text { Zimbabwe }\end{array}$ & $\begin{array}{l}\text { Democratic } \\
\text { Republic of } \\
\text { Congo, Rwanda, } \\
\text { Uganda }\end{array}$ & $\begin{array}{l}\text { Angola, } \\
\text { Burundi, } \\
\text { Ethiopia, } \\
\text { Mozambique, } \\
\text { Nigeria }\end{array}$ & $\begin{array}{l}\text { Central African } \\
\text { Republic, Chad, } \\
\text { Eritrea, Liberia, } \\
\text { Niger, Sudan }\end{array}$ \\
\hline
\end{tabular}

The facts and figures in this section demonstrate that the situation in Nigeria is worrisome and calls for far more drastic action than ever taken. Perhaps, the government may consider declaring a state of emergency in education as have been advocated by some analysts over the years and if this is done, priority attention should be given to the right to education.

\section{ESTIMATING THE TEACHER GAP IN NIGERIA}

A qualified teacher is one that has the competences in terms of the requisite knowledge, skills, values and conduct established for teachers at the national and international levels. It does not mean any one who is able to read or write, or able to stand in front of the classroom with a piece of chalk facing the writing board and a group of students. To be a teacher is to be a professional and the tenets of professionalism require that, among others, the individual has undergone the relevant professional education and has proven expertise in theory and practice as defined by the national and international teaching standards. This is the kind of qualified teacher implied by the theme of the World Teachers' Day.

As in the case of the out-of-school children, the UIS has figures about the shortage of qualified teachers at the international level but the figures for Nigeria is not very certain. Therefore, here again attempt is made to estimate the number of teachers required to cover the 15 million outof school children estimated for the country.

UNESCO [17] indicated that additional 3.2 million and 5.1 million teachers (making a total of 8.3 million) teachers are needed to prosecute the SDG4-Education. This figure excludes teacher attrition that may occur between 2015 and 2030. UIS [20] however put the total number of teachers required for primary and secondary education at 69 million. UNESCO [17] had also narrated the poor quality of existing teachers, stating that in some countries, over $75 \%$ of the teachers do not meet the national teaching standards. There is also lack of continuous professional development for the teachers and recruitment of unqualified teachers using the 
increase in school enrolment as excuse. Indeed, many factors and forces have been well documented $[38,18,39]$ as militating against the teaching profession. For example, UNESCO [18] raised alarm that teaching is being deprofessionalised and that the trend needs to be reversed. The African Union [38] study of the training, working and living conditions of teachers in African countries proved that many challenges are still entrenched. These and other challenges had made it difficult for many countries to face up to the challenge of transforming their basic education systems and guaranteeing the children's right to education.

For Nigeria, there is no available data of additional teachers required for SDG4-Education and the total number of teachers currently in the school system is largely speculative. The qualified teachers in public and private primary and secondary schools registered by the Teachers Registration Council of Nigeria since its inception in 2000 till 2018 is not up to 800,000. This fact was confirmed by Olusegun Ajiboye, Registrar Chief Executive of the Teachers Registration Council of Nigeria who, at the 2017 World Teachers Day, stated that there were over 300,000 unqualified teachers in the school system and this accounted for about $50 \%$ of the total number of teachers currently in the school system [40]. This suggests that there are about 600,000 teachers in school system.

But for 15 million out-of-school children alone, and using a student-teacher ratio of 30:1, 500,000 additional teachers will be required. When this is added to the 300,000 unqualified teachers already in the school system, there is a total of 800,000 teachers that need trained and retrained to close the teacher gap. The SDG4-Education is only twelve years away to the target date and it is clearly a difficult task for Nigeria to raise 800,000 additional qualified teachers before the date.

Even for the available teachers in the school system, both qualified and unqualified, the student-teacher ratio remains high. The UIS (2018b) revealed the existing student-teacher ratio globally. The data in the table 7 was extracted and grouped by the author from what the UIS [41] called the eAtlas of teachers, an interactive map that displays student-teacher ratio across the world. Nigeria belongs to group 3 with student-teacher ratio ranging from 30 to 39 students per teacher. However, practical experience on ground in Nigeria shows that studentteacher ratio is well over 40 students per teacher in most cases. The student-teacher ratio is one of the most critical indicators of the quality of instruction and the level of proficiency that students can attain. Nigeria therefore must strive to reduce this ratio. From the table, it is clear that countries with internationally celebrated education systems have a student-teacher ratio of less than 20:1. Among them are United Kingdom, Republic of Korea, Singapore, China, United States, Finland, Japan, Switzerland, Israel and Germany. 
Table 7: Student-teacher ratio across the world [41]

\begin{tabular}{|c|c|}
\hline $\begin{array}{c}\text { Group/ } \\
\text { Ratio }\end{array}$ & Countries/States \\
\hline $\begin{array}{l}\text { Group } 1 \\
50-83: 1\end{array}$ & $\begin{array}{l}\text { Central African Rep, Malawi, Rwanda, Chad, Mozambique, Ethiopia, Guinea Bissau, } \\
\text { Burundi. }\end{array}$ \\
\hline $\begin{array}{l}\text { Group } 2 \\
40-49: 1\end{array}$ & $\begin{array}{l}\text { Pakistan, Zambia, South Sudan, Guinea, Papa New Guinea, Benin, Congo, } \\
\text { Afghanistan, Eritrea, Cambodia, Cameroon, Uganda, Cote d'Ivoire, Tanzania, Angola, } \\
\text { Burkina Faso, Togo, Madagascar, Nauru. }\end{array}$ \\
\hline $\begin{array}{l}\text { Group } 3 \\
30-39: 1\end{array}$ & $\begin{array}{l}\text { Mali, Nigeria, Bhutan, Gambia, Sierra Leone, Somalia, Niger, Zimbabwe, } \\
\text { Mauritania, India, Bangladesh, Lesotho, Congo Dem. Rep., Senegal, Sao Tome and } \\
\text { Principe, Ghana, Djibouti, Timor-Leste, Kenya, Samoa, Namibia, Liberia, South } \\
\text { Africa, Philippines, Mongolia. }\end{array}$ \\
\hline $\begin{array}{l}\text { Group } 4 \\
20-29: 1\end{array}$ & $\begin{array}{l}\text { Nicaragua, Honduras, Comoros, Fiji, Myanmar, Eswatini, El Salvador, Vanuatu, Iran, } \\
\text { Morocco, Yemen, Mexico, Kiribati, Jamaica, Kyrgyzstan, Gabon, Solomon Islands, } \\
\text { Ecuador, United Arab Emirates, Palestine, Algeria, Paraguay, Colombia, Botswana, } \\
\text { Laos, Equatorial Guinea, Egypt, Sri Lanka, Guyana, Tonga, Nepal, Panama, Brazil, } \\
\text { Tajikistan, Guatemala, Belize, Korea DPR, Cabo Verde, Russian Federation, } \\
\text { Micronesia, Viet Nam, Uzbekistan. }\end{array}$ \\
\hline $\begin{array}{l}\text { Grol } \\
10-1\end{array}$ & $\begin{array}{l}\text { Bahama, Czechia, Dominican Republic, Kazakhstan, Armenia, Romania, Albania, } \\
\text { Bulgaria, Mauritius, Belarus, France, Bolivia, Trinidad and Tobago, Peru, Turkey, } \\
\text { Chile, Jordan, Bosnia/Herzegovina, Moldova, United Kingdom, Iraq, Slovenia, Cook } \\
\text { Islands, Singapore, Republic of Korea, China, Thailand, Argentina, Ireland, Japan, } \\
\text { Tunisia, Anguilla, Aruba, Serbia, Niue, Saint Lucia, St. Vincent/Grenadines, Grenada, } \\
\text { Slovakia, Azerbaijan, New Zealand, Croatia, Antigua and Barbuda, Suriname, TFYR } \\
\text { Macedonia, Gibraltar, United States, Hong Kong, Saint Kitts and Nevis, Monaco, } \\
\text { Seychelles, Puerto Rico, Indonesia, Macao, Spain, Portugal, Barbados, Malta, } \\
\text { Finland, Lithuania, Ukraine, Dominica, Cayman Islands, Tuvalu, Israel, Tokelau, } \\
\text { Saudi Arabia, Netherlands, Malaysia, Qatar, Cyprus, Lebanon, Italy, Costa Rica, } \\
\text { Sweden, Uruguay, Bahrain, British Virgin Island, Germany, Estonia, Montserrat, } \\
\text { Hungary, Denmark, Belgium, Saint Maarten, Latvia, Maldives, Brunei Darussalam, } \\
\text { Iceland, Greece, Poland, Andorra, Switzerland, Bermuda, Austria. }\end{array}$ \\
\hline $\begin{array}{l}\text { Group } 6 \\
6-9: 1\end{array}$ & $\begin{array}{l}\text { Turks and Caicos Island, Kuwait, Cuba, Norway, Georgia, Liechtenstein, } \\
\text { Luxembourg, San Marino. }\end{array}$ \\
\hline
\end{tabular}

\section{SOME INTERNATIONAL BEST PRACTICES REGARDING THE RIGHT TO EDUCATION}

Some of the key approaches towards addressing the right to education have been to make laws, provide extraordinary funding to target the vulnerable and accord priority to teacher quality. These key elements are found across the world in the countries that have demonstrated serious political will to improve their citizens' right to education. For instance:

i. The United States is an excellent example where law was made and backed with funds and political will to enhance the right of the vulnerable population to quality education.

ii. Finland, Singapore, Republic of Korea and Germany equally serve as very good examples of countries where teacher quality and status are very high and compete favourably with the quality and status of other professions.

Nigeria must reflect on these key strategies and the case of the United States and a few of these other countries are discussed in this section. First is the case of the United States and its famous "No Child Left Behind Act 2001" which aimed at catering for over 50 million children who were at the risk of losing their right to education. Rod Paige, the United States Secretary of Education at the time described the development as a new era of historic reform [42]. The Act gave the school districts power and flexibility to spend the education budget; set student 
achievement standards and invest money on evidence-based practices that work. It then held the schools and districts accountable for student achievement and parents had the right to change schools for their children and wards if their schools consistently fail to attain the required standards. The United States Department of Education [42] outlined the key features of the reform as follows:

i. Accountability - States became accountable for setting standards and targets for teachers and students.

ii. Flexibility and local control - States gained more autonomy to administer education at the state and local levels.

iii. Enhanced parental choice - Parents gained the freedom to hold the school districts accountable and to transfer their children to better schools at the cost of the school districts in some respects.

iv. Focuses on what works - Evidence based practices that work became key driver of the education system.

v. Teacher quality - Premium was placed on high quality initial and continuing teacher education and only the 'highly qualified' teachers and principals were considered fit enough for the schools. The 2005/2006 academic year was fixed to ensure that all teachers and principals attained the highly qualified status which implied that a teacher must have a bachelor's degree, teaching license and subject competences. [42]

Up till the current year, 2018, the United States is still vigorously pursuing the implementation of the No Child Left Behind Act as evidenced in the recent statements by Donald Trump, American President and the budgetary provisions of the current year. According to Trump, "education is the civil rights issue of our time." [43] He therefore called on the political parties to pass his education bill meant to fund "school choice" for African Americans, Latinos and other disadvantaged groups. In terms of funding, the United States budgeted significant sums of money for the education of the vulnerable in year 2018 as some of these examples demonstrate:

i. Support to States under "Title 1 Grants" to assist course work and teaching of 25 million children in very poor areas - $\$ 14.9$ billion.

ii. $\quad$ For individuals with disabilities $-\$ 12.7$ billion.

iii. To support acquisition of English language by teachers and students - \$736.0 million.

iv. Migrant education - $\$ 374.0$ million.

v. Rural education - $\$ 175.5$ million.

vi. Indian Education Grants - \$143.7 million.

vii. Education of children and youth who are homeless - $\$ 69.9$ million.

viii. Education of the neglected and delinquent - \$47.5 million. [43]

Overall, table 8 shows the funding of elementary and secondary education in the United States for 2015-2017.

Table 8: Funding of elementary and secondary education in the United States, 2015-2017 [48]

\begin{tabular}{|l|c|c|c|c|}
\hline \multirow{2}{*}{$\begin{array}{c}\text { Source of fund } \\
\text { by level }\end{array}$} & \multicolumn{2}{|c|}{ 2015-2016 } & \multicolumn{2}{c|}{ 2016-2017 } \\
\cline { 2 - 5 } & Billion Dollars & Per cent & Billion Dollars & Per cent \\
\hline Federal & $\$ 54.0$ & $7.7 \%$ & $\$ 55.0$ & $7.6 \%$ \\
\hline State & 305.0 & 43.1 & 316.0 & 43.3 \\
\hline Local & 284.0 & 40.2 & 294.0 & 40.2 \\
\hline All others & 64.0 & 9.0 & 65.0 & 8.9 \\
\hline Total & $\mathbf{7 0 7 . 0}$ & $\mathbf{1 0 0 . 0}$ & $\mathbf{7 2 7 . 0}$ & $\mathbf{1 0 0 . 0}$ \\
\hline
\end{tabular}


Turning now to teacher quality and the case of countries like Finland, Germany, Singapore and Republic of Korea, among others where "teaching works," this is no magic. The strategies are well known, clearly thought-out and systematically implemented over the years leading to their being on top of the world in terms of teacher quality and teacher status. Their teaching force is founded on the principle that the teacher is key to quality education, and that, of all factors involved in the education of the child, the most critical is the teacher. The United States Department of Education [44] put the fact succinctly: "Studies have shown the single greatest effect on student achievement is teacher quality. For this reason, America must remain steadfast in meeting the goal of ensuring that every classroom has a highly qualified teacher." Stronge and Hindman [45] equally reported research findings that proved that qualified teachers make the single greatest impact on learning. Therefore, they posited that though many factors such as curricula, class size, funding, and family backgrounds influence learning, none contributes to learning as much as the qualified teacher.

Furthermore, UNESCO [1] describes teachers as "one of the most influential and powerful forces for equity, access and quality in education and key to sustainable global development." Niemi, Toom and Kallioniemi [46] stated that Finland tops most countries of the world with respect to the performance of its 15- year old students in reading, mathematics and science in the Programme for International Student Assessment (PISA) instituted by the Organisation for Economic Co-operation and Development (OECD). The authors opined that such superlative performance could have been contributed by many factors but the most important were the very high quality, professionalism and status of the Finnish teachers. According to their report, in Finland, candidates admitted for initial teacher education are among the best; a minimum of a Master's degree is required to enter the profession on full time bases; selection process for teacher recruitment is rigorous; and teacher competencies and professionalism are of the highest possible standards [46]. These cases show that for Nigeria to achieve the right to education, funding and teacher quality, among others, must receive an unprecedented attention

\section{A MODEL ILLUSTRATING THE AFRICAN STRATEGY FOR ADDRESSING THE TEACHER GAP}

The African Union and its continental and global partners are unrelenting in their efforts to bridge the teacher gap in Africa. Among the partners are UNESCO, UNESCO-International Institute for Capacity Building in Africa (IICBA), International Task Force on Teachers for Education 2030, Africa Federation of Teaching Regulatory Authority (AFTRA), and Education International Africa Region. A coalition of these organisations have conducted research, held high level conferences and policy forums, made declarations, and commissioned the development of a number of continental frameworks aimed at comprehensively tackling the challenge of the teacher gap. Since these are complex and multifarious activities and programmes, space will not permit to discuss them in detail. This is why a model (see figure 2) has been chosen to represent the programmes and activities. 
Figure 2: Model of the efforts at the international level to address the teacher gap

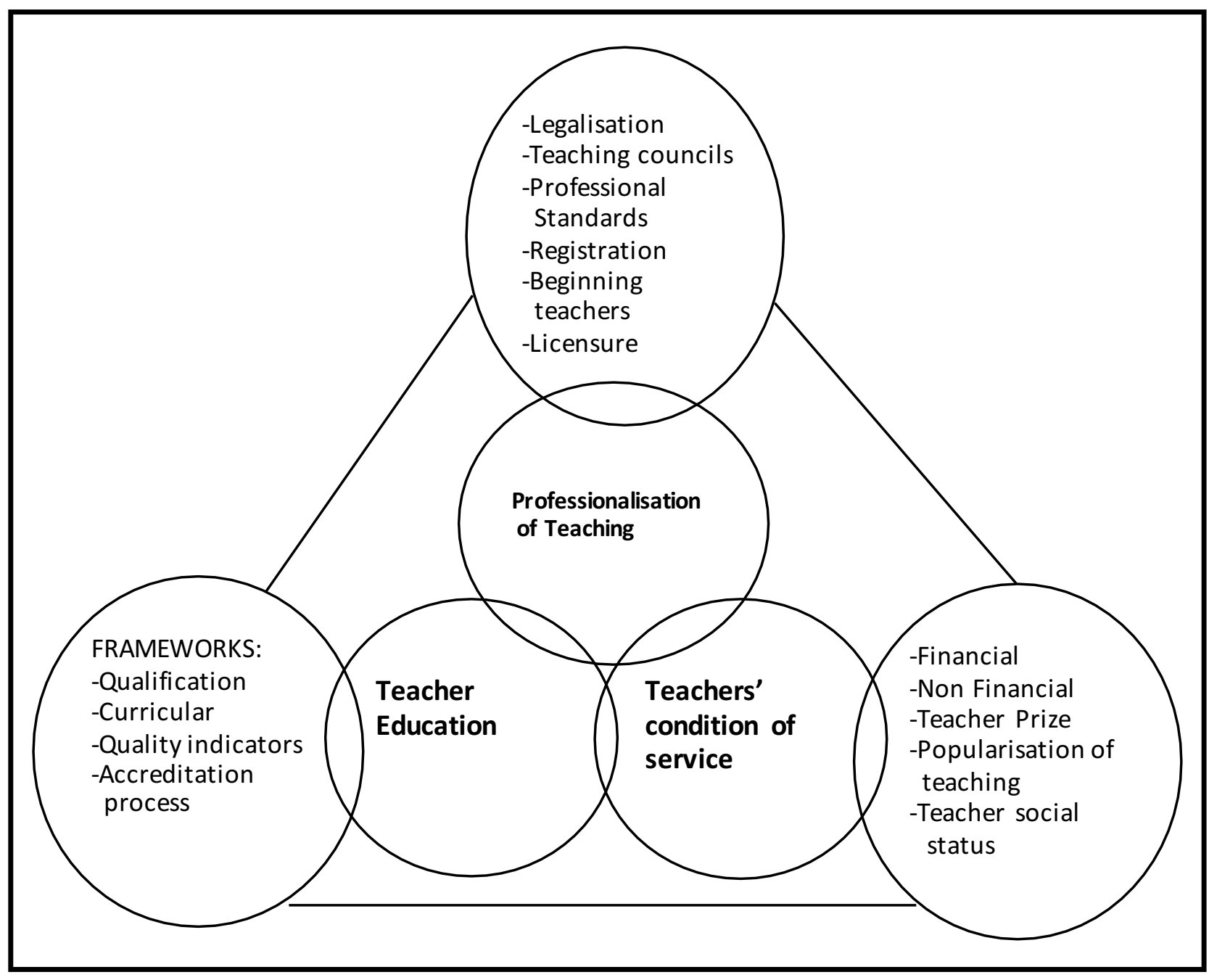

The model shows the three key thrusts which are the professionalization of teaching, teacher education and teacher conditions of service. All the three key thrusts are guided by the SDG4-Education especially the details of the Incheon Declaration and Framework for Action for the implementation of SDG4 [17]; Agenda 2063: The Africa We Want [13]; and the Continental Education Strategy for Africa, CESA 2016-2025 [14]. The number one aspiration of Agenda 2063 is: "A prosperous Africa based on inclusive growth and sustainable development" whereas the first of the twelve strategic objectives of CESA is to: "Revitalize the teaching profession to ensure quality and relevance at all levels of education." These are powerful aspirations and strategic objectives considered overarching in the African interventions.

Also, the Outcome of the $10^{\text {th }}$ Policy Dialogue Forum of the International Task Force on Teachers for Education 2030 held in Lome, Togo, called for the entrenchment of teaching as a clinical practice, that is, a profession akin to medicine where precision, competences and integrity will be the foundations of practice [47]. The theme of that $10^{\text {th }}$ Policy Forum was "Teaching: A Profession." The theme was carefully chosen to underscore the urgency and priority attention that must be given globally at this time to the professionalization of teaching. The theme of the Task Force's $11^{\text {th }}$ Policy Forum scheduled to take place in Jamaica, in November, 2018 again is "Strengthening teacher education: A prerequisite for quality teaching and learning". The themes which are now consistently on the teaching profession demonstrate the consensus in the global community about the imperatives of the 
professionalization of teaching. There was also a high-level pan African Conference on Education (PACE) convened by the African Union and UNESCO and hosted by the Government of Kenya, April 25-27, 2018 [48]. PACE was called to update and harmonise all critical interventions taking place across Africa with respect to SDG4-Education, Agenda 2063 and CESA 2016-2025. PACE further endorsed the three key thrusts mentioned above.

Now, the complex activities of each of the three key thrusts are briefly outlined below.

\section{Professionalisation of teaching}

There is a global consensus that teaching must be professionalised and that already established professions such as medicine and law are the benchmarks. The professionalization constitutes several issues but a few of them are:

i. Legalisation - Countries must enact laws to legalise teaching. The general belief is that teaching cannot be adequately regulated outside a clear legal framework as in the other established professions.

ii. Teaching councils - The law should create a professional regulatory agency (commonly called teaching councils) to drive the professionalization of teaching.

iii. Professional standards - The profession must be founded on professional standards that will be the pivot of all other aspects such as teacher education, assessment, reward, and career advancement.

iv. Registration - Teachers must be registered like other professionals.

v. Beginning teachers - Induction, internship and mentoring programmes are necessary for beginning teachers.

vi. Licensure - Teachers should hold teaching license as other professionals do.

vii. Mobility protocol - An African Teacher Mobility Protocol is being developed to facilitate the movement of teachers across international borders especially to areas of teacher shortage.

\section{Teacher education}

A continental teacher education framework is being developed to set benchmarks for critical aspects of teacher education such as:

i. Teacher qualification - to establish generic teacher qualification benchmarks and qualification routes and apply the International Standard Classification of Education (ISCED) developed by the UIS [49]. The application of ISCED is to ensure that concepts and data generated for the continental teacher education frameworks fit into the global education information management system.

ii. Teacher education curricula - to develop generic and pedagogical content of teacher education that Africans hold in common or desire.

iii. Teacher education quality indicators - to establish continental quality indicators of acceptable teacher education at given levels of ISCED.

iv. Teacher education accreditation process - to establish African best practices for quality assurance in teacher education including teaching practice.

The framework is expected to cover both the initial and continuing teacher education because teacher education is regarded as a continuum.

\section{Teachers' condition of service}

The teachers' condition of service is among the worrisome issues in the profession. Compensating and motivating teachers are very complex and sometimes tricky. It may be tricky because while many people believe that all that teachers care about is financial reward, some findings prove that other tangible and intangible issues strongly affect the teachers' 
motivation equally. A very important and recent study by the UNESCO-International Institute for Capacity Building in Africa [39] on teacher motivation analysed many essential motivation requirements of teachers apart from salaries. The findings pointed to the importance of social dialogue that gives teachers a voice in the development of education policy; teacher professional development; teacher appraisal and evaluation; and school improvement and community involvement. These and other issues are believed to create a supportive teaching and learning environment that boost the teachers' self-worth and make them feel valued. On the bases of the foregoing, the following are currently receiving attention at the continental level:

i. Financial incentives - Strategies for improving the pay of teachers to be commensurate with the economic realities of the member states.

ii. Non-Financial incentives - The intangible ways of giving teachers a meaningful life including health, education, social insurance, pension and family support.

iii. Teacher Prize - Instituting competitive continental prize to honour teachers that demonstrate high impact and performance.

iv. Popularisation of teaching - Advocacy with member states and other critical stakeholders to address factors militating against the teaching profession.

v. Teacher social status - Looking comprehensively on all issues affecting the teachers' social status as revealed by several research findings. As stated by UNESCO [18] "teachers are a fundamental condition for guaranteeing quality education, teachers and educators should be empowered, adequately recruited and remunerated, motivated, professionally qualified, and supported within well-resourced, efficient and effectively governed systems."

\section{CONCLUSION/RECOMMENDATIONS}

The denial of a fundamental human right, especially the right to education, is a misadventure that can plunge the world into socio-economic and political catastrophe in the years to come. Education is key to achieving all the SDGs, therefore anything that impedes the achievement of the right to education equally poses as threat to the realisation of all the SDGs. This paper has therefore raised vital issues surrounding the right to education globally and in Nigeria as well as the critical importance of a quality teaching force. The complexity of the problem has been $\mathrm{x}$ rayed and international best practices highlighted. The lessons from these can be powerful guide for designing Nigeria's action plan for right to education. The actions must be backed by political will to reverse the deprofessionalisation of teaching and close the teacher gap. Lastly, the professionalization of teaching is a collective responsibility of all stakeholders including the employers of teachers in the public and private sectors. Their support and commitment to the implementation of the emerging African frameworks will greatly promote the success and fortunes of the profession and advance the right to education.

\section{Recommendations}

Based on the analysis of the paper, the following actions are recommended:

i. The task is enormous and urgent; therefore, the federal government may consider declaring a state of emergency for basic education and the teaching force.

ii. The federal and state governments and stakeholders need to commission a study to map and profile the vulnerable persons in Nigeria who are at risk of losing their right to education in order to obtain comprehensive and credible statistics of the out-of-schoolchildren.

iii. The governments at all levels need to also commission a study to determine the statistics of teachers required to execute SDG4-Education in Nigeria and strategies to produce the required number. 
iv. The successful implementation of the right to education requires a political will from all stakeholders especially federal and state governments and employers of teachers in the private sector.

v. The inability of the country to enforce the national minimum teaching qualification (which is the Nigeria Certificate in Education), 43 years of the approval of the policy is a litmus test that indicates serious weakness in the implementation and enforcement of educational policies. The least the country could do is to enforce this critical decadesold policy.

vi. The government should aspire to meet the funding benchmark established by the African Union for education in the member states, which is 4-6\% of national GDP or 15$20 \%$ of annual total public expenditure.

vii. The three dimensions of the international model for addressing the teacher gap should be pursued more vigorously - the professionalisation of teaching, teacher education (initial and CPD) and teachers' conditions of service.

viii. The cases of countries like Finland, South Korea, Singapore, and Germany should be studied further with a view to garnering best practices and adapting them to the Nigerian context.

ix. Nigeria must be mindful of its population growth rate compared with its slow rate of economic growth. There is actually need for a serious social and population policy that can aim at aligning the national demographics to reality. This will require carefully designed national advocacy and enlightenment programmes.

\section{References}

UNESCO (2018a). World teachers' day: The right to education means the right to a qualified teacher. https://en.unesco.org/commemorations/worldteachersday

ILO/UNESCO (1966). The recommendation concerning the status of teachers. Paris: UNESCO.

UNESCO (1997). Recommendation concerning the status of higher-education teaching personnel. Paris: UNESCO.

Carlsen, G.R. (1979). American literature: Themes and perspectives. New York: McGraw-Hill Book Company.

Patel, J. (2007). Human rights education.

https://www.researchgate.net/publication/274908579 (Accessed 01/10/2018)

Lee, S.E. (2013). Education as a human right in the 21st Century. Democracy \& Education, 21(1): 1-9.

United Nations (1948). Universal declaration of human rights. New York: UN.

Right to Education Project (2014). International instruments: Right to education. London: ActionAid International.

UNESCO et al (1990). Final report: World declaration on education for all - Meeting basic learning needs, Jomtien, Thailand, 5-9 March.

UNESCO (2000). World education report: The right to education - Towards education for all throughout life. Paris: UNESCO.

United Nations (2000). United Nations Millennium Declarations. New York: UN

United Nations (2015). Transforming our world: The 2030 agenda for sustainable development. New York: UN.

African Union (2016a): Agenda 2063: The Africa we want. Addis Ababa: AU.

African Union (2016b). Continental education strategy for Africa (CESA 16-25). Addis Ababa: AU.

UNICEF \& UNESCO (2007). A human rights-based approach to education for all: A framework for the realization of children's right to education and rights within education. New York: UNICEF.

UNESCO (2017). Unpacking Sustainable Development Goal 4 Education 2030. Paris: UNESCO.

UNESCO (2015). Incheon Declaration and Framework for Action for the implementation of Sustainable Development Goal 4 Ensure inclusive and equitable quality education and promote lifelong learning opportunities for all. Paris: UNESCO.

UNESCO (2015). Rethinking education towards a global common good? Paris: UNESCO. 
UNICEF \& UNESCO Institute for Statistics (2015). Global out-of-school children initiative. New York: UNICEF.

UNESCO Institute for Statistics (2018a). One in five children, adolescents and youth is out of school. Fact Sheet No. 48, February UIS/FS/2018/ED/48.

UNESCO Institute for Statistics (2017). Global monitoring report: Reducing global poverty through universal primary and secondary education. Policy paper 32/Fact Sheet 44

UNICEF Nigeria (2018). Quality Basic Education: The situation.

https://www.unicef.org/nigeria/education.html (Accessed 25/9/2018)

Adepegba, A. (2018). Politicians exploiting 'almajiris' - Chief Imam. Punch newspapers, May 26.

(http://punchng.com/politicians-exploiting-almajiris-chief-imam/)

Aworinde, T. (2018). Why the North will still vote for Buhari in 2019 -Matthew Kukah. Punch Newspapers, April

15. http://punchng.com/why-the-north-will-still-vote-for-buhari-in-2019-matthew-kukah/ (Accessed

11/10/2018).

This Day (2017). Containing the almajiri phenomenon. This Day, June 7.

https://www.thisdaylive.com/index.php/2017/06/07/containing-the-almajiri-phenomenon/ (Accessed

01/10/2018)

Index Mundi (2018). Nigeria - Children out of school, primary.

https://www.indexmundi.com/facts/nigeria/children-out-of-school (Accessed 11/10/2018)

Woldometers (2018). Nigeria population (live).

http://www.worldometers.info/world-population/nigeria-population/ (Accessed 11/10/2018)

United States Agency for International Development (2011). Nigeria Northern Education Initiative (NEI) results of the early grade reading assessment (EGRA) in Hausa. Abuja: NEI.

Universal Basic Education Commission (2012). National assessment of universal basic education programme (NAUBEP) 2006, 2009 Final reports. Abuja: UBEC

Federal Republic of Nigeria (2004a). Compulsory, free universal basic education act. Laws of the Federal Republic of Nigeria. Abuja: Government Printer.

Federal Republic of Nigeria (2004b). National Commission for Nomadic Education Act. Laws of the Federal Republic of Nigeria. Abuja: Government Printer.

Federal Republic of Nigeria (2004c). National Commission for Mass Literacy, Adult andNon-Formal Education, etc. Act. Laws of the Federal Republic of Nigeria. Abuja: Government Printer.

Federal Republic of Nigeria (1999). Constitution of the Federal Republic of Nigeria. Abuja: Government Printer.

National Bureau of Statistics (2018). Key indicators. http://www.nigerianstat.gov.ng/ (Accessed 11/10/2018)

Uwais, M. (2018). 67\% Nigerians live below poverty line.

https://www.vanguardngr.com/2018/01/67-nigerians-live-poverty-line-presidential-aide/ (Accessed $11 / 10 / 2018)$

Ujah, E. (2018). Human development index: World Bank ranks Nigeria 152nd out of 157 countries. Vanguard, October 11. https://www.vanguardngr.com/2018/10/human-devt-index-w-bank-ranks-nigeria-152nd-out-of157-countries/ (Accessed 25/09/2018)

Bashir, S.; Lockheed, M.; Ninan, E.; \& Tan, J. (2018). Facing forward: Schooling for learning in Africa. Washington, DC.: World Bank Group.

African Union (2017). Study on teacher training, working and living conditions in member states. Addis Ababa: AUC.

UNESCO International Institute for Capacity Building in Africa (2017). Teacher support and motivation framework for Africa: Emerging patterns. Addis Ababa: IICBA.

Iredia, T. (2018). Rising trend of unqualified teachers. Vanguard, November 12.

https://www.vanguardngr.com/2017/11/rising-trend-unqualified-teachers/ (Accessed 11/10/2018)

UNESCO Institute of Statistics (2018b). UNESCO eAtlas of teachers.

https://tellmaps.com/uis/teachers/\#!/tellmap/873758989 (Accessed 25/9/2018)

United States Department of Education (2002). No child left behind: A desktop reference. Washington, D.C.: US

Department of Education. 
United States Department of Education (2018). Fiscal year 2018 budget: Summary and background information https://www2.ed.gov/about/overview/budget/budget18/summary/18summary.pdf (Accessed 26/9/2018)

United States Department of Education (2004). A guide to education and no child left behind. Washington, D.C.: Office of Public Affairs.

Stronge, J.H. \& Hindman, J.L. (2003). Hiring the best teachers. Educational Leadership, 60(8):48-52.

Niemi, H., Toom, A. \& Kallioniemi A. (2012). Miracle of education: The principles and practices of teaching and learning in Finnish schools, cited in UNESCO (2015). Rethinking education: Towards a global common good? Paris: UNESCO.

International Task Force on Teachers for Education 2030 (2017). Outcome statement of the 10th Policy Dialogue held in Lome, Togo, September 18-21.

African Union (2018). Report of the pan African high-level conference on education, Nairobi, Kenya, 25-27 April. UNESCO Institute for Statistics (2012). International Standard Classification of Education, ISCED 2011. Montreal: UIS. 